\title{
Effects of Climate Change in Aquaculture: Case study in Thua Thien Hue Province, Vietnam
}

\author{
Le Duc Ngoan* \\ University of Agriculture and Forestry, Hue University, Vietnam
}

Received: 䀺: October 08, 2018; Published: 拝: October 15, 2018

*Corresponding author: Le Duc Ngoan, University of Agriculture and Forestry, Hue University, Vietnam

\section{Abstract}

Thua Thien Hue province, a coastal province in Central Vietnam has strongly affected by climate change, especially in aquaculture production. This paper reviews the results of household survey and key informant reviewing on effect of steam climate events and natural disasters affect aquaculture in five districts of the province.

\section{Introduction}

Viet Nam's topography, climate and long coastline makes it particularly vulnerable to climate extremes and natural disasters. The country has around $3,260 \mathrm{~km}$ of coastline and over 3,000 islands, where more than 70 percent of its population live. Dasgupta et al. (2007) suggested that Viet Nam is one of the World's top five most vulnerable countries to sea level rise and the most vulnerable to climate change (CC) impacts in South East Asia. Thua Thien Hue as a central coastal province has $128 \mathrm{~km}$ of coastline and around 22,000 ha of Tam Giang lagoon. More than $30 \%$ of the provincial population live around Tam Giang lagoon and earn living by directly or indirectly exploiting the natural resources in the lagoon (Binh et al., 2010). Aquaculture is a major component of the economy of Thua Thien Hue, its development is regarded as top priority (Tuong et al., 2008).

This report is the result of a survey of 120 households and number of group and key informant interviews and consultant meetings in five districts of Thua Thien Hue province.

\section{Effect of High Temperature}

Water temperature plays an important role in the growth and development of the organism in general and particular to aquatic animals. In the tropics, hot weather had made water temperature increased over the tolerance of many species [1]. The results of household survey showed that in recent years, the phenomenon of prolonged hot weather has caused great impact on aquaculture activities (65\% respondent). This has caused great impact on aquaculture production activities. Increasing temperatures are not only conditions made the disease occurs more and more but also made the water quality became worse, this is the good condition for pathogen develop. Disease happened more frequency, in the recent years, due to habitat degradation associated with extreme changes of weather, climate, leading to disease outbreaks and caused shrimps died in large quantity, slow growth and disease occur simultaneously in many places has led to low production efficiency [2,3]. More information form aqua culturist showed that apart from common diseases like white spot, MBV, there were some phenomenon of mortality but could not identified the pathogen.

\section{Effect of Natural Disasters}

Some typical effects of natural disasters and other extreme weather events can be seen clearly and directly affected to aquaculture that are: small flood come earlier, and cyclones appeared to be more in recent years. Previously, the storm usually occurs in September, but in recent years storms, tropical low pressure happened earlier, can occur any month of the year, frequency of flooding with more intense, so that aqua culturist could not respond and have solution. Many households lost fish and shrimp in large numbers. Another phenomenon is that prolonged rain, at the beginning of crop, rain had continuous up to 3-4 months, made salinity and temperature were low, fish grew slowly. Then June -July, prolonged hot, salinity greatly increased, fish grew slowly, so that prolong the culture period [4]. The impact of natural disasters, unstable weather, accompanied by causing environmental pollution, fingerling is low quality, those are the main reasons of changing productivity.

\section{Effect of Erosion and Changing Flow}

The phenomenon of sea erosion, estuaries landslide, many aquaculture areas were affected, particularly the communes of Phu Thuan, Phu An, Phu Dien (Phu Vang district), and communes of Vinh Hai and Vinh Hien (Phu Loc district) [5]. The phenomenon of flow changes, as shrinking sea-opening, affect tidal amplitude, tidal amplitude in Thuan an outlet was recorded from 0.5 to $0.7 \mathrm{~m}$ 
before, but now only about from 0.3 to $0.4 \mathrm{~m}$, slow flow rate, water flow is block, difficult to get water into the shrimp farming ponds, especially the area far away from the lagoon.

\section{Conclusion}

Through data analysis and assessments collected we found that in recent years, weather conditions and climate in Thua Thien Hue province is complicated, unusual changes such as drought, prolonged hot weather, cold weather lasting, tidal amplitude changes, storms, floods, ... has seriously affected agricultural activities in general and in particular aquaculture production. of which, the aquaculture sector is considered one of the vulnerable and most affected by the impacts of CC [6]. Despite the attention of the authorities, the efforts of the community and response of the people but due to the strength of the disaster and occurs with more intensity, so people still have not adequate solutions to cope effectively with CC, therefore, it is needed to intergrate adaptation to $\mathrm{CC}$ in to overall development plans of the department to help local people better cope with climate change for sustainable development.

\section{ISSN: 2574-1241}

DOI: $10.26717 / B J S T R .2018 .10 .001892$

Le Duc Ngoan. Biomed J Sci \& Tech Res

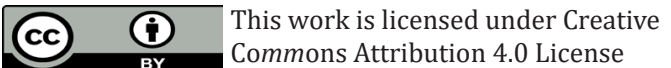

Submission Link: https://biomedres.us/submit-manuscript.php

\section{References}

1. (2009) ADB The Economics of Climate Change in Southeast Asia: A Regional Review.

2. Binh MN, NTT Thuy, NTH Giang, HTT Hoai, TV Dan, et al. (2010) Impact of climate change on aquaculture in Phu Vang district, Thua Thien Hue province, Vietnam. SEARCA Agriculture \& Development, Discussion Paper Series No 2016(3): 48.

3. Dasgupta, S Laplante, Benoit, Meisner, Craig, Wheeler, David and J Yan (2007) The Impact of Sea Level Rise on Developing Countries: A Comparative Analysis. World Bank Policy Research Working Paper No 4136.

4. De Silva SS and Soto D (2009) Climate change and aquaculture: potential impacts, adaptation and mitigation In Climate change implications for fisheries and aquaculture: overview of current scientific knowledge. In: Cochrane K et al. (Eds.). FAO Fisheries and Aquaculture Technical Paper. No. 530. Rome, pp. 151-212.

5. FAO (2008) Climate change for Fisheries and Aquaculture.

6. Tuong LN, TM Kien, T Thuc, T Quynh (2008) Climate Change Impacts in Huong River Basin and Adaptation in its Coastal District Phu Vang, Thua Thien Hue Province. Final Report, National Climate Change Program. Hanoi, Vietnam.

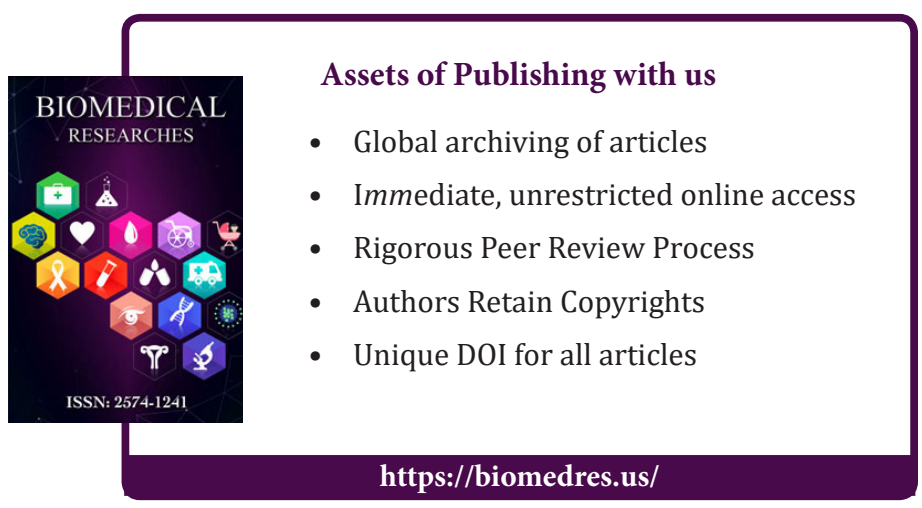

